\title{
Taxonomic Position of Aromatic-Degrading Denitrifying Pseudomonad Strains K 172 and KB 740 and Their Description as New Members of the Genera Thauera, as Thauera aromatica sp. nov., and Azoarcus, as Azoarcus evansii sp. nov., Respectively, Members of the Beta Subclass of the Proteobacteria
}

\author{
HANS-JOACHIM ANDERS, ${ }^{1}$ ANETTE KAETZKE, ${ }^{1}$ PETER KÄMPFER, ${ }^{2} \dagger$ \\ WOLFGANG LUDWIG, ${ }^{3}$ AND GEORG FUCHS ${ }^{1,4 *}$ \\ Abteilung Angewandte Mikrobiologie und Mykologie, Universität Ulm, Ulm, ${ }^{1}$ Fachgebiet Hygiene, Technische \\ Universität Berlin, Berlin, ${ }^{2}$ Lehrstuhl für Mikrobiologie, Technische Universität München, Munich, ${ }^{3}$ and \\ Lehrstuhl für Mikrobiologie, Institut für Biologie II, Universität Freiburg, Freiburg, ${ }^{4}$ Germany
}

\begin{abstract}
In the past workers have isolated several pseudomonad strains which have been used for studies of anaerobic aromatic metabolism. The best studied of these strains are strains $K B 740^{T}\left(T=\right.$ type strain) and $K 1^{T}$. The taxonomic positions of these two organisms were determined by classical methods, including experiments to determine substrate spectrum, quinone type, and total fatty acid composition. Our results clearly excluded these strains from the authentic genus Pseudomonas, which belongs to the gamma subclass of the Proteobacteria. Instead, the properties of these organisms indicated that they belong to the beta subclass of the Proteobacteria. The sequences of the $16 \mathrm{~S}$ ribosomal DNA genes confirmed this conclusion and indicated that strain $\mathrm{K} 172^{\mathrm{T}}$ represents a new species of the genus Thauera, Thauera aromatica, and that strain $\mathrm{KB} 740^{\mathrm{T}}$ represents a new species of the genus Azoarcus, Azoarcus evansii.
\end{abstract}

The anaerobic metabolism of aromatic compounds is one of the major unsolved problems of bacterial metabolism. This process has been investigated mainly with pure cultures of known phototrophic bacteria (15) and with denitrifying bacteria (14) whose systematic position is uncertain. These organisms have often been referred to as pseudomonad strains which have some properties in common with members of the genus Pseudomonas; i.e., they have gram-negative, aerobic, rodshaped cells with polar flagella. However, only the members of the Pseudomonas fluorescens branch, in the gamma subclass of the Proteobacteria, represent the authentic pseudomonads (46).

A number of different denitrifying bacteria have been isolated under denitrifying conditions by using aromatic substrates such as 2-aminobenzoate, phenol, and benzoate as sole carbon and energy sources $(4,43)$. A rapid genotyping method in which low-molecular-weight RNA profiles were used (17) indicated that these strains are not Pseudomonas strains belonging to rRNA group I (31) and that some of the strains might belong to the same genospecies. For example, strains $\mathrm{KB}$ $740^{\mathrm{T}}$ (4) ( $\mathrm{T}=$ type strain), KB 650 (4), and B4P (40) could form one genospecies, whereas strains K $172^{\mathrm{T}}$, S $100(43)$, and S 2 (40) might form another, separate genospecies. This separation is also supported by physiological properties, such as utilization of certain aromatic substrates under denitrifying conditions. For example, the strains of the second genospecies $\left(\mathrm{K} 172^{\mathrm{T}}, \mathrm{S} 100, \mathrm{~S} 2\right)$ could use phenol $(43)$ or toluene $(1,39)$ as sole organic substrates under denitrifying conditions, whereas the members of the first genospecies (KB $\left.740^{\mathrm{T}}, \mathrm{KB} 650, \mathrm{~B} 4 \mathrm{P}\right)$ could not.

\footnotetext{
* Corresponding author. Mailing address: Angewandte Mikrobiologie, Universität Ulm, D-89069 Ulm, Germany. Phone: 0731/5022710. Fax: 0731/5022719.

$\dagger$ Present address: Institut für Hygenie und Umweltmedizin, RWTH Aachen, Aachen, Germany.
}

In this study, a polyphasic strategy was used to classify strains $\mathrm{KB} 740^{\mathrm{T}}$ and $\mathrm{K} 172^{\mathrm{T}}$, which are the most extensively studied members of these two groups. Phenotypic characteristics, such as fatty acid composition and quinone type, suggested that these strains belong to the beta subclass of the Proteobacteria. The exact phylogenetic positions of these organisms were further analyzed by determining $16 \mathrm{~S}$ ribosomal DNA (rDNA) sequences.

\section{MATERIALS AND METHODS}

Materials. Chemicals and biochemicals were obtained from Merck (Darmstadt, Germany), Fluka (Neu-Ulm, Germany), Sigma (Heidelberg, Germany), Roth (Karlsruhe, Germany), Difco (Hamburg, Germany), Boehringer (Mannheim, Germany), United States Biochemicals (Braunschweig, Germany), and Pharmacia (Freiburg, Germany). Gases were obtained from Linde (Höllriegelskreuth, Germany). Pseudomonad strain KB $740^{\mathrm{T}}$ (= DSM $6898^{\mathrm{T}}$ ) was a kind gift from Konstantin Braun (4), and pseudomonad strain K $172^{\mathrm{T}}$ (= DSM 6984 ${ }^{\mathrm{T}}$ ) was isolated in our laboratory (43). Escherichia coli JM 109 (= DSM 3423) was obtained from the Deutsche Sammlung von Mikroorganismen (Braunschweig, Germany). Plasmid vector pBluescript SK $+1-$, which was obtained from Stratagene (Heidelberg, Germany), was used as a cloning vector.

Growth of bacteria. Strain KB $740^{\mathrm{T}}$ was cultivated anaerobically at $28^{\circ} \mathrm{C}$ with $5 \mathrm{mM}$ benzoate and $20 \mathrm{mM}$ nitrate as the sole sources of energy and cell carbon (4). Strain $\mathrm{K} 172^{\mathrm{T}}$ was grown with $1 \mathrm{mM}$ phenol and $4 \mathrm{mM}$ nitrate as described elsewhere (43). Growth determination, cell harvesting, and storage at $-70^{\circ} \mathrm{C}$ were performed as described previously (10). E. coli JM 109 cultures were grown in Luria-Bertani broth. E. coli JM 109 cells containing a plasmid were cultivated in Luria-Bertani broth supplemented with $100 \mu \mathrm{g}$ of ampicillin per $\mathrm{ml}$ or on $1.5 \%$ agar plates supplemented with $100 \mu \mathrm{g}$ of ampicillin per $\mathrm{ml}, 0.4 \mathrm{mM}$ isopropylthio- $\beta$-D-galactoside, and $0.1 \mathrm{mM}$ 5-bromo-4-chloro-3-indolyl- $\beta$ - $\mathrm{D}$-galactoside (2).

Phenotypic characterization. Morphological and biochemical characteristics and carbon substrate assimilation test results were determined as described elsewhere $(4,20,43)$.

Chemotaxonomic characterization. Cellular fatty acids were extracted from cultures that had been cultivated aerobically at $25^{\circ} \mathrm{C}$ for $48 \mathrm{~h}$ in $\mathrm{R} 2 \mathrm{~A}$ medium. The fatty acids were methylated with methanolic $\mathrm{HCl}$, and the fatty acid methyl esters obtained were analyzed by gas-liquid chromatography, using a Shimadzu model GC 9A chromatography apparatus equipped with a fused-silica capillary column $(50 \mathrm{~m}$ by $0.32 \mu \mathrm{m})$, as described elsewhere (19). Ubiquinones were extracted and analyzed exactly as described by Collins (9).

Isolation of genomic DNA. A culture ( 1 liter) $\left(A_{578}, 0.7\right)$ was harvested by 
centrifugation at $10,000 \times g$ and $4^{\circ} \mathrm{C}$ for $10 \mathrm{~min}$. The cells were resuspended in $9.5 \mathrm{ml}$ of $10 \mathrm{mM}$ Tris-HCl (pH 8.0)-1 mM EDTA. The cells were lysed by adding $0.5 \mathrm{ml}$ of $10 \%(\mathrm{wt} / \mathrm{vol})$ sodium dodecyl sulfate and $50 \mu \mathrm{l}$ of a proteinase $\mathrm{K}$ solution $(20 \mathrm{mg} / \mathrm{ml})$ and then incubating the preparation at $37^{\circ} \mathrm{C}$ for $1 \mathrm{~h}$. After lysis, $1.8 \mathrm{ml}$ of $5 \mathrm{M}$ sodium chloride and $1.5 \mathrm{ml}$ of $10 \%(\mathrm{wt} / \mathrm{vol})$ hexadecyltrimethylammonium bromide in $0.7 \mathrm{M}$ sodium chloride were added, and the crude extract was incubated at $65^{\circ} \mathrm{C}$ for $20 \mathrm{~min}$. The hexadecyltrimethylammonium bromide-sodium chloride solution removed exopolysaccharides and proteins (2) The crude extract was purified with an equal volume of chloroform-isoamyl alcohol $(24: 1, \mathrm{vol} / \mathrm{vol})$, and the nucleic acids were precipitated with 0.6 volume of ice-cold isopropyl alcohol. The pellet was washed with $70 \%$ ethanol, dried, and redissolved in $10 \mathrm{mM}$ Tris- $\mathrm{HCl}$ ( $\mathrm{pH} 8.0)-1$ mM EDTA. This nucleic acid solution contained considerable amounts of RNA. The RNA was removed by treatment with an RNase A solution $(20 \mathrm{ng} / \mathrm{ml})$ for $1 \mathrm{~h}$ at $37^{\circ} \mathrm{C}$. The DNA concentration was determined spectrophotometrically.

PCR amplification, cloning, and sequencing of the 16S rRNA genes. A 100-ng portion of bacterial DNA was used in each reaction mixture. Each reaction mixture (total volume, $100 \mu \mathrm{l}$ ) also contained $50 \mathrm{mM} \mathrm{KCl}, 10 \mathrm{mM}$ Tris- $\mathrm{HCl}(\mathrm{pH}$ 8.3 ), $2 \mathrm{mM} \mathrm{MgCl}$, $2.5 \mathrm{mM}$ dATP, $2.5 \mathrm{mM} \mathrm{dCTP}, 2.5 \mathrm{mM} \mathrm{dGTP}, 2.5 \mathrm{mM}$ dTTP and amplification primers, each at a concentration of $0.3 \mu \mathrm{M}$. The reaction mixture was overlaid with $100 \mu$ l of mineral oil $(25,28,36)$.

First, the chromosomal DNA was denatured at $94^{\circ} \mathrm{C}$ for $5 \mathrm{~min}$. The samples were then cooled to $80^{\circ} \mathrm{C}$, and $2.5 \mathrm{U}$ of Taq DNA polymerase (Ampli Taq Perkin-Elmer Cetus, Überlingen, Germany) was added. Each of the 30 amplification cycles included denaturation at $94^{\circ} \mathrm{C}$ for $1 \mathrm{~min}$, primer annealing at temperatures between 48 and $64^{\circ} \mathrm{C}$ for $1.3 \mathrm{~min}$, and extension at $72^{\circ} \mathrm{C}$ for $2 \mathrm{~min}$; this was followed by a final extension step at $72^{\circ} \mathrm{C}$ for $10 \mathrm{~min}$. The $16 \mathrm{~S}$ rDNA gene was amplified between positions 28 and 1528 (E. coli numbering system [5]) with the following primer combination: forward primer 5'-ATA TGC GGC CGC AGA GTT TGA TYM GGC TCA G-3' and reverse primer 5'-ATA TGC GGC CGC AGA AAG GAG GTG ATC C $-3^{\prime}(\mathrm{Y}=\mathrm{C}$ or $\mathrm{T} ; \mathrm{M}=\mathrm{A}$ or $\mathrm{C})$. To purify the PCR products, the mineral oil was extracted with chloroform. The bacterial genomic DNA, excess primer, and nucleotides were separated from the aqueous phase with "Magic prep" spin columns (Promega/Serva, Heidelberg, Germany) according to the instructions of the distributor (26). The amplified and purified DNA fragments were cloned in the vector pBluescript (Stratagene). The resulting recombinant plasmids, $\mathrm{K} 1$ (strain $\mathrm{K} 172^{\mathrm{T}}$ ) and $\mathrm{KB} 1$ (strain $\mathrm{KB} 740^{\mathrm{T}}$ ), were transformed and amplified in E. coli JM 109. The amplified plasmid DNA was isolated with a Qiagen plasmid kit (Diagen, Hilden, Germany) according to the instructions of the distributor.

The recombinant plasmids were sequenced by the dideoxy chain termination method (37), and the purified PCR products were sequenced directly (8). We used universal or reverse primers that bound to vector sequences or synthetic oligonucleotides complementary to specific regions of the 16S rDNA gene. Sequencing was carried out by using the instructions of the manufacturer and a Sequenase 2.0 sequencing kit (United States Biochemicals). The termination reaction mixtures were separated on a $6 \%$ polyacrylamide gel with $8 \mathrm{M}$ urea by using $89 \mathrm{mM}$ Tris-borate- $89 \mathrm{mM}$ boric acid-2 mM EDTA (24). After drying, the gels were analyzed by autoradiography overnight at room temperature with Kodak X-Omat film (Sigma, Deisenhofen, Germany).

Analysis of data. The new $16 \mathrm{~S}$ rDNA sequences were added to an alignment of about 1,800 homologous primary structures from bacteria $(21,29)$ by using the alignment tool of the ARB program package (42). Phylogenetic analyses were performed by using distance matrix maximum-parsimony and maximum-likelihood methods and the corresponding tools of the ARB (42) and PHYLIP (12) program packages, as well as the fastDNAm1 program (21). The compositions of the data sets varied with respect to the reference sequences as well as the alignment positions included. Variability at individual positions was determined by using the tools in the ARB package; the resulting data were used as criteria to remove or include variable positions. Data sets comprising all of the available, almost complete 16S rRNA sequences of members of the beta subclass of the Proteobacteria and selected representatives of other major bacterial lines of descent were analyzed by using distance matrix and maximum-parsimony methods. Subsets that included the corresponding sequences of the closest relatives of strains $\mathrm{KB} 740^{\mathrm{T}}$ and $\mathrm{K} 172^{\mathrm{T}}$, as well as selected representatives of the major phylogenetic groups of the beta subclass of the Proteobacteria, were used for maximum-likelihood analyses.

Nucleotide sequence accession numbers. The rDNA sequences of strains $K$ $172^{\mathrm{T}}$ and $\mathrm{KB} 740^{\mathrm{T}}$ have been deposited in the EMBL database under accession numbers X77118 and X77679, respectively. "Azoarcus denitrificans" sequences have been deposited by Zhou et al. in the EMBL data library. The accession numbers of these sequences and other sequences used to determine levels of $16 \mathrm{~S}$ rRNA similarity are as follows: Azoarcus evansii, X77679; " $A$. denitrificans" Td-1 L33687; " $A$. denitrificans" Td-2, L33691; " $A$. denitrificans" Td-3, L33693; " $A$. denitrificans" Tol-4, L33694; "A. denitrificans" Td-15, L33688; "A. denitrificans" Td-17, L33689; " $A$. denitrificans" Td-19, L33690; "A. denitrificans" Td-21, L33692; "Azoarcus" sp. strain BH72, L15530; Azoarcus indigens, L15531; Thauero aromatica, X77118; Thauera selenatis, X68491; Zoogloea ramigera ATCC 19544 ${ }^{\mathrm{T}}$ X74913; Rhodocyclus purpureus, M34132; Rhodocyclus tenuis, D16208; strain ToN1, X83534; strain EbN1, X83531; strain PbN1, X83532; and strain mXyN1, $\mathrm{X} 83533$.

\section{RESULTS AND DISCUSSION}

Well-studied pseudomonad strains $\mathrm{K} 172^{\mathrm{T}}$ and $\mathrm{KB} 740^{\mathrm{T}}$ were preliminarily placed in the genus Pseudomonas on the basis of some common physiological and morphological properties. These organisms were gram negative and oxidase positive and were not able to ferment sugars. A large variety of organic acids and aromatic compounds and some amino acids could be oxidized both aerobically and with nitrate as an electron acceptor. Under aerobic conditions strain $\mathrm{K} 172^{\mathrm{T}}$ used benzoate, 2-aminobenzoate, 3-hydroxybenzoate, 4-hydroxybenzoate, 4-hydroxyphenylacetate, phenylacetate, gentisate, phenylalanine (slow growth), butyrate, isobutyrate, propionate, isovalerate, adipate, glutarate, acetate, glycerophosphate, glycolate, D-lactate, L-lactate, DL-lactate, L-malate, oxaloacetate, L-asparagine, L-glutamate, L-isoleucine, L-leucine, $\mathrm{L}$-serine, and $\beta$-alanine as sole carbon sources, but did not use 4-aminobenzoate, vanillate, fructose, 2-oxoglutarate, D-tartrate, $m$-tartrate, L-tartrate, L-aspartate, L-lysine, L-ornithine, L-phenylalanine, L-proline, or L-valine; under anaerobic conditions this strain used benzoate, toluene, phenol, phenylacetate, phenylglyoxylate, 2-hydroxybenzoate, 3-hydroxybenzoate, 4-hydroxybenzoate, protocatechuate, 2-aminobenzoate (slow growth), 4-hydroxyphenylacetate, phenylalanine (poor or uncertain growth), $p$-cresol, benzaldehyde, benzyl alcohol, indole, indolylacetate, glutarate, succinate, fumarate, L-malate, acetate, and ethanol but did not use $o$-cresol, $m$-cresol, 2-fluorobenzoate, $o$-phthalate, adipate, pimelate, cyclohexanecarboxylate, D-glucose, D-fructose, D-maltose, D-ribose, or D-lactose $(1,43)$. Under aerobic conditions strain $\mathrm{KB} 740^{\mathrm{T}}$ used benzoate, 2aminobenzoate, 4-aminobenzoate, 3-hydroxybenzoate, 4-hydroxyphenylacetate, phenylacetate, vanillate, gentisate, phenylalanine, fructose, butyrate, isobutyrate, propionate, isovalerate, glutarate, acetate, glycolate, D-lactate, L-lactate, DL-lactate, L-malate, oxaloacetate, 2-oxoglutarate, D-tartrate, $m$-tartrate, L-tartrate, L-asparagine, L-aspartate, L-glutamate, L-isoleucine, L-leucine, L-lysine, L-ornithine, L-phenylalanine, L-serine, L-proline, L-valine, and $\beta$-alanine as sole carbon sources but did not use 4-hydroxybenzoate, adipate, or glycerophosphate; under anaerobic conditions this strain used benzoate, phenylacetate, phenylglyoxylate, 3-hydroxybenzoate, 4-hydroxybenzoate, 2-aminobenzoate, 4-hydroxyphenylacetate, phenylalanine, $p$-cresol, 2-fluorobenzoate, benzaldehyde, benzyl alcohol, indolylacetate, $o$-phthalate, adipate, pimelate, glutarate (slow growth), cyclohexanecarboxylate, succinate, fumarate, L-malate, acetate, acetone, D-glucose (slow growth), $\mathrm{D}$-fructose, and D-maltose but did not use toluene, phenol, 2-hydroxybenzoate, protocatechuate, $o$-cresol, $m$-cresol, indole, ethanol, D-ribose, or D-lactose $(4,27,38)$. Growth with some of these compounds was very slow. A comparison of the reaction profile with previously published data did not allow unambiguous identification, although most of the other properties (see below) indicated that these strains were more closely related to the genera Acidovorax, Comamonas, Variovorax, and Hydrogenophaga, than to the genus Pseudomonas. These genera have been recognized as members of a new bacterial family, the Comamonadaceae, in rRNA superfamily III (in the beta subclass of the Proteobacteria); members of this family reportedly are closely related genotypically and rather diverse phenotypically (44). Accumulation of poly- $\beta$-hydroxybutyrate (e.g., by strain $\mathrm{K} 172^{\mathrm{T}}$ ) is also a characteristic that distinguishes the $\beta$-subgroup species from authentic Pseudomonas species, which do not accumulate this compound.

Fatty acid patterns and quinone type. The fatty acid profiles of strains $\mathrm{K} 172^{\mathrm{T}}$ and $\mathrm{KB} 740^{\mathrm{T}}$ were very similar (Table 1 ). In addition to the two main fatty acids, cis-9-hexadecenoate (16:1) 
TABLE 1. Characteristics of pseudomonad strains $\mathrm{K} 172^{\mathrm{T}}$ and $\mathrm{KB} 740^{\mathrm{T}}$, T. selenatis, A. indigens, Z. ramigera ATCC $19544^{\mathrm{T}}$, and $P$. aeruginosa ATCC 10145

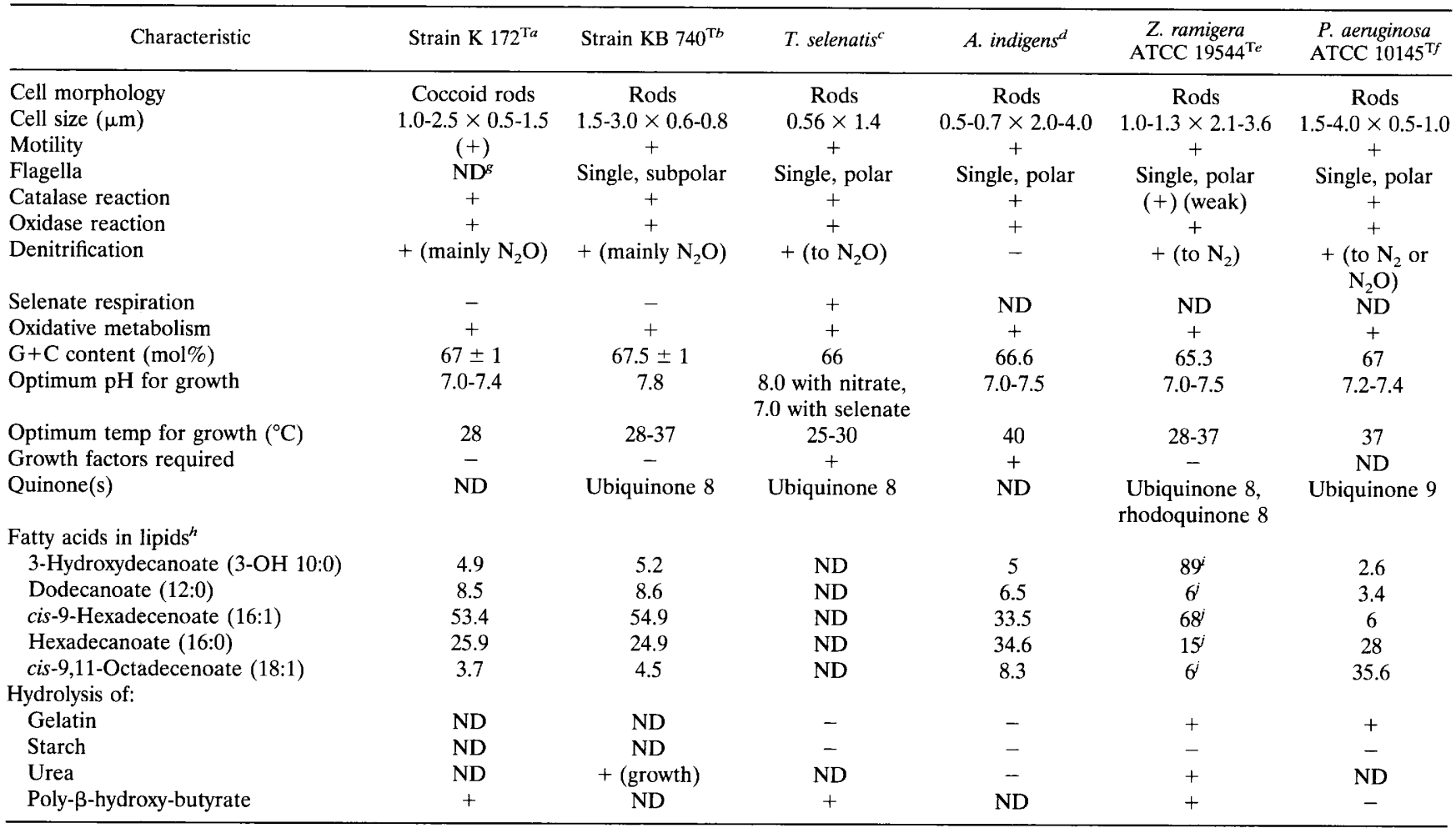

${ }^{a}$ Some data were obtained from reference 43.

${ }^{b}$ Some data were obtained from reference 4

${ }^{c}$ Data from reference 23 .

${ }^{d}$ Data from reference 34 .

'Data from references $16,18,31$, and 35 .

${ }^{f}$ Data from references 3,22 , and 30 .

${ }^{g} \mathrm{ND}$, not determined.

${ }^{h}$ Unless indicated otherwise, values are percentages of the total fatty acids.

${ }^{i}$ Percentage of 3-OH fatty acids.

${ }^{j}$ Percentage of nonpolar fatty acids.

and hexadecanoate (16:0), small amounts of 3-hydroxydecanoate (3-OH 10:0) were also found. These fatty acid profiles were similar to the profiles described for other members of the beta subclass of the Proteobacteria (45) and were different from the profiles described for members of the authentic genus Pseudomonas (41). Notably, the lack of hydroxylated fatty acids other than 3-OH 10:0 is a strong argument against assignment to the genus Pseudomonas whose members contain more than one hydroxylated fatty acid. The fatty acid profiles are consistent with placement of the strains in the acidovorans rRNA cluster sensu De Ley (11) but not in the authentic genus Pseudomonas.

Also, the quinone type found, ubiquinone 8 , is consistent with this conclusion. Ubiquinone 8 is the major quinone found in members of the beta subclass, whereas ubiquinone 9 is the characteristic quinone found in the authentic pseudomonads $(6,7)$. A summary of these properties and other features of the strains which we studied and related members of the beta subclass of the Proteobacteria, is shown in Table 1.

Phylogeny and taxonomic position. The rDNA sequences of strains $\mathrm{K} 172^{\mathrm{T}}$ and $\mathrm{KB} 740^{\mathrm{T}}$ were determined and compared with about 1,800 homologous sequences from other bacteria. This comparison showed that both organisms are members of the beta subclass of the Proteobacteria and that neither is related to the authentic pseudomonads, which belong to the gamma subclass. Among the beta subclass of the Proteobacte- ria, strains $\mathrm{K} 172^{\mathrm{T}}$ and $\mathrm{KB} 740^{\mathrm{T}}$ cluster with a major phylogenetic group that includes representatives of the genera Azoarcus, Rhodocyclus, Thauera, and Zoogloea. The closest relative of strain $\mathrm{K} 172^{\mathrm{T}}$ is $T$. selenatis (23), whereas strain $\mathrm{KB} 740^{\mathrm{T}}$ clusters with toluene-degrading " $A$. denitrificans" strains (13); the overall levels of sequence similarity are 97.7 and 98.5 to $99.4 \%$, respectively (Table 2 ). Two other denitrifying toluenedegrading strains, $\mathrm{mXyN1}$ and ToN1 (32), cluster with $\mathrm{K} 172^{\mathrm{T}}$ and $\mathrm{KB} 740^{\mathrm{T}}$, respectively. The levels of sequence similarity with two members of the gamma subclass, Pseudomonas aeruginosa and Chromatium vinosum, are approximately $81 \%$ for both strains.

The phylogenetic tree in Fig. 1 shows the positions of denitrifying strains KB $740^{\mathrm{T}}$ and $\mathrm{K} 172^{\mathrm{T}}$ in the beta subclass of the Proteobacteria. The positions of close relatives of these organisms and selected representatives of the major phylogenetic groups of the beta subclass are also shown. The tree is based on the results of maximum-likelihood analyses. To avoid treeing artifacts in the lower branches, data for highly variable positions were successively removed from the data set used to perform various analyses with the sequences. Such artifacts may result from ambiguous alignment of variable regions or from false identities as a consequence of multiple base changes during the course of evolution. The tree was further evaluated by performing distance matrix and maximum-parsimony anal- 
TABLE 2. Overall levels of $16 \mathrm{~S}$ rDNA sequence similarity for $A$. evansii, $T$. aromatica, and related reference organisms belonging to the beta subclass of the Proteobacteria ${ }^{a}$

$\begin{array}{lllllllllllllllllllllllllllll}\text { Ae } & \text { A19 } & \text { A3 } & \text { A21 } & \text { A17 } & \text { A15 } & \text { ToN1 } & \text { A1 } & \text { A4 } & \text { A2 } & \text { EbN1 } & \text { PbN1 } & \text { AB } & \text { Ai } & \text { Ta } & \text { mXyN1 Ts } & \text { Zr } & \text { Rp }\end{array}$

\begin{tabular}{|c|c|c|c|c|c|c|c|c|c|c|c|c|c|c|c|c|c|c|c|}
\hline A19 & 99.0 & & & & & & & & & & & & & & & & & & \\
\hline $\mathbf{A} 3$ & 99.2 & 99.0 & & & & & & & & & & & & & & & & & \\
\hline A21 & 99.4 & 98.8 & 98.8 & & & & & & & & & & & & & & & & \\
\hline A17 & 99.2 & 98.3 & 98.4 & 99.1 & & & & & & & & & & & & & & & \\
\hline Als & 99.4 & 98.9 & 99.0 & 99.0 & 99.2 & & & & & & & & & & & & & & \\
\hline Al & 98.8 & 98.1 & 98.2 & 98.3 & 98.4 & 98.6 & 98.8 & & & & & & & & & & & & \\
\hline A4 & 98.8 & 97.9 & 98.2 & 98.3 & 98.4 & 98.6 & 98.8 & 99.9 & & & & & & & & & & & \\
\hline $\mathrm{A} 2$ & 98.5 & 97.8 & 98.2 & 98.2 & 98.2 & 98.4 & 98.6 & 99.6 & 99.6 & & & & & & & & & & \\
\hline EbN1 & 95.6 & 95.7 & 96.2 & 96.1 & 96.5 & 96.4 & 96.4 & 97.2 & 97.2 & 97.0 & & & & & & & & & \\
\hline $\mathrm{AB}$ & 95.3 & 95.3 & 95.9 & 95.5 & 95.9 & 95.9 & 95.9 & 96.4 & 96.4 & 96.2 & 95.6 & 95.5 & & & & & & & \\
\hline $\mathrm{Ai}$ & 95.5 & 94.9 & 95.3 & 95.0 & 95.1 & 95.1 & 95.5 & 95.5 & 95.5 & 95.3 & 95.5 & 95.3 & 97.4 & & & & & & \\
\hline $\mathrm{Ta}$ & 94.3 & 93.2 & 93.7 & 93.9 & 94.2 & 93.8 & 94.2 & 93.9 & 93.9 & 93.6 & 92.6 & 93.6 & 94.3 & 94.5 & & & & & \\
\hline mXyN 1 & 94.6 & 93.6 & 94.1 & 94.2 & 94.4 & 94.1 & 94.5 & 94.2 & 94.2 & 93.9 & 94.6 & 93.9 & 94.8 & 94.8 & 99.6 & & & & \\
\hline Ts & 93.8 & 93.1 & 93.7 & 93.4 & 93.5 & 93.2 & 93.8 & 93.6 & 93.5 & 93.3 & 93.5 & 93.2 & 94.0 & 94.2 & 97.7 & 98.0 & & & \\
\hline $\mathrm{Zr}$ & 93.0 & 92.1 & 92.4 & 92.6 & 93.1 & 92.7 & 93.1 & 92.7 & 92.7 & 92.5 & 91.4 & 92.6 & 93.1 & 92.4 & 92.7 & 92.8 & 91.7 & & \\
\hline $\mathbf{R p}_{\mathbf{p}}$ & 90.9 & 90.4 & 90.8 & 90.1 & 90.7 & 90.5 & 91.0 & 90.8 & 90.9 & 90.6 & 90.6 & 91.4 & 91.3 & 91.6 & 91.0 & 91.3 & 91.8 & 91.5 & \\
\hline Rt & 90.7 & 90.3 & 90.7 & 90.5 & 90.7 & 90.5 & 90.8 & 90.9 & 91.1 & 90.7 & 90.3 & 90.6 & 91.2 & 90.7 & 90.4 & 90.6 & 90.8 & 91.3 & 96.4 \\
\hline
\end{tabular}

a The complete sequences (length, $1495 \mathrm{bp}$ ) between the PCR primers were determined; these sequences corresponded to positions 28 to 1528 in the $E$. coli system (5). Abbreviations: Ae, A. evansi; A1, "A. denitrificans" Td-1; A2, "A. denitrificans" Td-2; A3, "A. denitrificans" Td-3; A4, "A. denitrificans" Tol-4; A15, "A. denitrificans" Td-15; A17, "A. denitrificans" Td-17; A19, "A. denitrificans" Td-19; A21, "A. denitrificans" Td-21; AB, "Azoarcus" sp. strain BH72; Ai, A. indigens; Ta, T. aromatica; $\mathrm{Ts}, T$. selenatis; $\mathrm{Zr}, Z$. ramigera ATCC $19544^{\mathrm{T}}$; Rp, R. purpureus; Rt, $R$. tenuis.

yses of comprehensive data sets that differed with respect to the inclusion of variable positions and outgroup reference organisms.

In Fig. 1, multifurcations indicate branches for which a relative order could not be determined unambiguously or was not supported by the results obtained when different treeing methods were used. The affiliations of the strains which we studied and their closest relatives are shown in Fig. 2. Because we wanted to resolve close relationships, all sequence positions were included for construction of this tree. The highly variable positions provided valuable phylogenetic information useful for the elucidation of close relationships. As described above, artifacts are unlikely to occur when very similar sequences are compared. In the case of the "A. denitrificans" strains (13) and the two other toluene-degrading strains (ToN1 and mXyN1) (32) the relationships are too close (Table 2) for all of these organisms to be properly resolved by comparative $16 \mathrm{~S}$ rDNA analysis. To indicate the depth of the group, only strains Td-1 and strain KB $740^{\mathrm{T}}$ were included.

Comparison with species belonging to the genera Thauera and Azoarcus. The high level of sequence similarity between strain $\mathrm{K} 172^{\mathrm{T}}$ and the type strain of $T$. selenatis suggests that strain $\mathrm{K} 172^{\mathrm{T}}$ is a Thauera strain. T. selenatis is characterized by a unique property-it reduces selenium oxyanions under anaerobic conditions (33). Strain $\mathrm{K} 172^{\mathrm{T}}$ was tested for selenate reduction by using benzoate or acetate as an electron donor, but no selenate reduction was detected under these conditions. In addition, the rDNA gene sequences exhibited a difference of $2.3 \%$ (Table 2). Therefore, we suggest that strain $\mathrm{K} 172^{\mathrm{T}}$ is a new species of this genus, for which we propose the name Thauera aromatica. Recently, Rabus and Widdel (32) described a closely related toluene-degrading denitrifier, strain $\mathrm{mXyN1}$, which was not able to use phenol.

The 16S rDNA sequence data revealed that strain KB $740^{\mathrm{T}}$ exhibited high levels of similarity (98.5 to $99.4 \%$ ) (Table 2) with homologous sequences from " $A$. denitrificans" strains (13) deposited by Zhou et al. in the EMBL data library and with the homologous sequence of isolate ToN1 $(99.8 \%$ ) (Table 2) described by Rabus and Widdel (32), strains which use toluene as a substrate under denitrifying conditions. This suggests that these strains are members of a common genus and that they belong to the same species. However, this group is only moderately closely related to the validly described type species $A$. indigens (34), as shown in Fig. 2 and indicated by mean overall levels of sequence similarity of 94.9 to $95.5 \%$. There are also some major phenotypic differences. For instance, it has been 


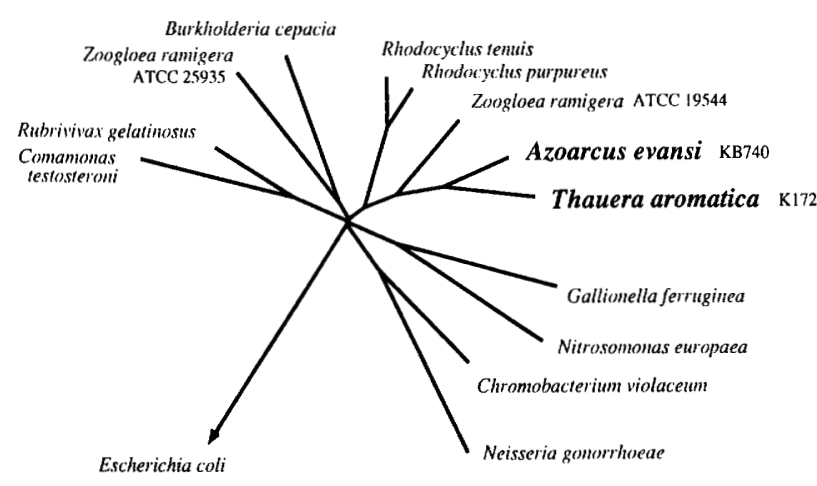

$10 \%$

FIG. 1. Phylogenetic tree showing the phylogenetic positions of the denitrifying organisms $A$. evansii $\mathrm{KB} 740^{\mathrm{T}}$ and $T$. aromatica $\mathrm{K} 172^{\mathrm{T}}$, as well as selected relatives in the beta subclass of the Proteobacteria, as determined from $16 \mathrm{~S}$ rRNA sequences. The topology was evaluated by performing maximum-parsimony and distance matrix analyses of comprehensive data sets. Bar $=10 \%$ estimated sequence divergence.

reported that members of the genus Azoarcus do not denitrify, are not able to use benzoate aerobically, and grow with monosaccharides aerobically. However, recent investigations have shown that Azoarcus strains in fact do denitrify, yet none of the strains was able to grow with benzoate under denitrifying conditions (33a). Strain KB $740^{\mathrm{T}}$ clearly denitrifies and grows aerobically and under denitrifying conditions with benzoate and fructose, and preliminary tests have indicated that it fixes molecular nitrogen, in contrast to strain $\mathrm{K} 172^{\mathrm{T}}$ (unpublished data). We suggest that strain $\mathrm{KB} 740^{\mathrm{T}}$, the related " $A$. denitrificans" strains, and strain ToN1, which have not been validly described yet, should be grouped together in one species. As long as information concerning differentiating characteristics is limited, the new species may be placed in the genus Azoarcus. Since strain KB $740^{\mathrm{T}}$ and the other strains mentioned above differ in many properties from members of the genus Thauera and from members of the validly described Azoarcus species, we suggest that strain $\mathrm{KB} 740^{\mathrm{T}}$ belongs to a new species of the genus Azoarcus, for which we propose the name Azoarcus evansii.

Unfortunately, none of the previously described Azoarcus strains was available for comparison; these organisms have not been deposited in culture collections even though they are members of a new genus. The only species of the genus Thauera that has been described previously, $T$. selenatis, has been deposited in the American Type Culture Collection; however, the type strain has been patented and therefore was not available for comparison. Other denitrifying strains, such as strains SP, S 100, U 120, S 2, B4P, which were isolated in our laboratory, have somewhat different morphological properties, differ in their substrate spectra, or have been enriched with media containing aromatic substrates different from those used for strain KB $740^{\mathrm{T}}$ (anthranilate) and strain K $172^{\mathrm{T}}$ (phenol). These organisms will be investigated in a future comprehensive study which includes other newly isolated denitrifying, aromatic-degrading strains and, we hope, the previously described Azoarcus and Thauera strains.

Amendment of the description of the genus Thauera. Selenate is used as the electron acceptor by some strains. Vitamins are required for growth by only some strains. The substrates used for growth given in the original genus description are the substrates used by $T$. selenatis. Since strain $\mathrm{K} 172^{\mathrm{T}}$ cannot use all of the substrates used by the type strain, the list

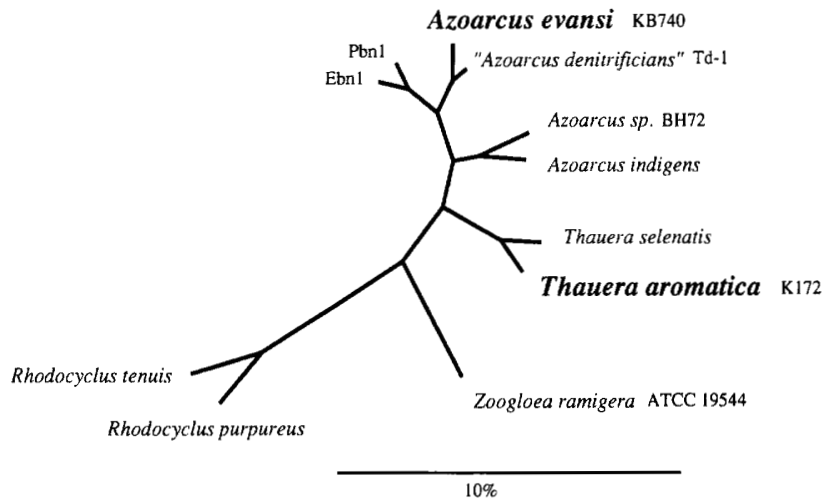

FIG. 2. Phylogenetic tree showing the relationships of $A$. evansii, T. aro matica, and related strains. All sequence positions were included for the calculations. Strains Pbn1 and Ebn1 are denitrifiers that grow anaerobically with ethylbenzene (32). Bar $=10 \%$ estimated sequence divergence.

of substrates should be redefined when more representatives of the genus Thauera are known.

Description of Thauera aromatica sp. nov. Thauera aromatica (ar.o.ma' ti.ca. M. L. adj. aromatica, aromatic, because the organism was isolated on media containing aromatic compounds as sole carbon sources). Gram-negative, rod-shaped cells are 1.0 to $2.5 \mu \mathrm{m}$ long and 0.5 to $1.5 \mu \mathrm{m}$ wide, have rounded ends, and accumulate poly- $\beta$-hydroxybutyrate. Cells are slightly motile. Colonies on defined medium containing benzoate are $1 \mathrm{~mm}$ in diameter and white after 4 to 5 days of aerobic growth at $28^{\circ} \mathrm{C}$. No growth or poor growth occurs at $37^{\circ} \mathrm{C}$ and on complex media. Grows aerobically or anaerobically with nitrate on minimal media. Cells do not reduce selenate or ferment sugars. Many aromatic compounds are used as sole carbon sources under denitrifying conditions. The aromatic substrates are metabolized to $\mathrm{CO}_{2}$. During growth with aromatic compounds nitrite is an intermediate and is reduced mainly to $\mathrm{N}_{2} \mathrm{O}$. No vitamins are required for growth. The optimum growth temperature is around $28^{\circ} \mathrm{C}$. The optimum $\mathrm{pH}$ for growth is between 7 and 7.4. Cells are catalase and oxidase positive. Phylogenetically, T. aromatica is a member of the beta subclass of the Proteobacteria. This organism was isolated from anaerobic sludge by using media containing phenol and nitrate. The type strain is K 172 (= DSM 6984). The DNA base composition is $67 \mathrm{~mol} \% \mathrm{G}+\mathrm{C}$. For additional characteristics of the type strain see above and Table 1.

Description of Azoarcus evansii sp. nov. Azoarcus evansii (e'van.si.i. L. gen. n. evansii, of Evans, in honor of the late W. C. Evans, a pioneer in studies of anaerobic aromatic metabolism). Cells are rods with rounded ends and are 1.5 to $3 \mu \mathrm{m}$ long and 0.6 to $0.8 \mu \mathrm{m}$ wide. Each cell is motile by means of one subpolarly inserted flagellum. Gram negative and $\mathrm{KOH}$ positive. Oxidase and catalase positive. Colonies on minimal media containing benzoate are 1 to $2 \mathrm{~mm}$ in diameter and white or beige after 3 to 4 days of incubation at $28^{\circ} \mathrm{C}$. Yeast extract $(0.1 \%, \mathrm{wt} / \mathrm{vol})$ inhibits growth. The optimum growth temperature is around $37^{\circ} \mathrm{C}$, and the optimum $\mathrm{pH}$ is around 7.8. No growth occurs at $41^{\circ} \mathrm{C}$. Strictly oxidative metabolism occurs with oxygen or nitrate as the terminal electron acceptor. During growth with aromatic compounds nitrite is an intermediate and is reduced mainly to $\mathrm{N}_{2} \mathrm{O}$. Positive in the oxidative oxidation-fermentation test with different sugars. No fermentation occurs. In the presence of nitrate a variety of aromatic substrates are used anaerobically as sole carbon sources as are some sugars, dicarboxylic acids, and cyclohexanecarboxylate. 
Several L-amino acids are growth substrates for aerobic growth. The major fatty acids are cis-9 16:1, 16:0, 12:0, 3-OH 10:0, and cis-9,11 18:1. The major quinone is ubiquinone $8 . A$. evansi is a member of the beta subclass of the Proteobacteria. The type strain is KB 740 (= DSM 6898). Isolated by K. Braun and D. T. Gibson from creek sediment in the United States with media containing 2-aminobenzoate and nitrate (4). The base composition of the DNA is $67.5 \mathrm{~mol} \% \mathrm{G}+\mathrm{C}$. Additional morphological, biochemical, and nutritional features are summarized above and in Table 1.

\section{ACKNOWLEDGMENTS}

This work was supported by the Deutsche Forschungsgemeinschaft through Schwerpunktprogramm "Neuartige Reaktionen und Katalysemechanismen in anaeroben Mikroorganismen," by Land Baden-Württemberg through project "Wasser - Abfall - Boden," and by Fonds der Chemischen Industrie.

\section{REFERENCES}

1. Altenschmidt, U., and G. Fuchs. 1991. Anaerobic degradation of toluene in denitrifying Pseudomonas sp.: indication for toluene methylhydroxylation and benzoyl-CoA as central aromatic intermediate. Arch. Microbiol. 156: 152-158.

2. Ausubel, F. M., R. Brent, R. E. Kingston, D. D. Moore, J. G. Seidman, J. A Smith, and K. Struhl (ed.). 1994. Current protocols in molecular biology. John Wiley and Sons, Inc., New York.

3. Bergan, T. 1981. Human- and animal-pathogenic members of the genus Pseudomonas, p. 666-700. In M. P. Starr, H. Stolp, H. G. Trüper, A. Balows, and H. G. Schlegel (ed.), The prokaryotes, vol. 1. Springer-Verlag, Berlin.

4. Braun, K., and D. T. Gibson. 1984. Anaerobic degradation of 2-aminobenzoate (anthranilic acid) by denitrifying bacteria. Appl. Environ. Microbiol. 48:102-107.

5. Brosius, J., M. L. Palmer, P. J. Kennedy, and H. F. Noller. 1978. Complete nucleotide sequence of a $16 \mathrm{~S}$ ribosomal RNA gene from Escherichia coli. Proc. Natl. Acad. Sci. USA 75:4801-4805.

6. Busse, H. J., T. El-Banna, and G. Auling. 1989. Evaluation of different approaches for identification of xenobiotic-degrading pseudomonads. Appl. Environ. Microbiol. 55:1578-1583

7. Busse, H. J., T. El-Banna, H. Oyaizu, and G. Auling. 1992. Identification of xenobiotic-degrading isolates from beta subclass of the Proteobacteria by a polyphasic approach including $16 \mathrm{~S}$ rRNA partial sequencing. Int. J. Syst. Bacteriol. 42:19-26.

8. Casanova, J.-L., C. Pannetier, C. Jaulin, and P. Kourilsky. 1990. Optimal conditions for directly sequencing double-stranded PCR products with sequenase. Nucleic Acids Res. 18:4028.

9. Collins, M. D. 1985. Isoprenoid quinone analysis in bacterial classification and identification, p. 267-288. In M. Goodfellow and D. E. Minnikin (ed.) Chemical methods in bacterial systematics. Academic Press, New York.

10. Dangel, W., R. Brackmann, A. Lack, M. Mohammed, J. Koch, B. Oswald, B. Seyfried, A. Tschech, and G. Fuchs. 1991. Differential expression of enzyme activities initiating anoxic metabolism of various aromatic compounds via benzoyl-CoA. Arch. Microbiol. 155:256-262.

11. De Vos, P., A. van Landschoot, P. Segers, R. Tytgat, M. Gillis, M. Bauwens, R. Rossau, M. Goor, B. Pot, K. Kersters, P. Lizzaraga, and J. De Ley. 1989. Genotypic relationships and taxonomic localization of unclassified Pseudomonas and Pseudomonas-like strains by deoxyribonucleic acid-ribosomal ribonucleic acid hybridizations. Int. J. Syst. Bacteriol. 39:35-49.

12. Felsenstein, J. 1982. Numerical methods for inferring phylogenetic trees. Q. Rev. Biol. 57:379-404.

13. Fries, M. C., J. Zhou, J. Chee-Sanford, and J. M. Tiedje. 1994. Isolation, characterization, and distribution of denitrifying toluene degraders from a variety of habitats. Appl. Environ. Microbiol. 60:2802-2810.

14. Fuchs, G., M. Mohamed, U. Altenschmidt, J. Koch, A. Lack, R. Brackmann, C. Lochmeyer, and B. Oswald. 1994. Biochemistry of anaerobic biodegradation of aromatic compounds, p. 513-553. In C. Ratledge (ed.), Biochemistry of microbial degradation. Kluwer Academic Publishers, Dordrecht, The Netherlands.

15. Harwood, C. S., and J. Gibson. 1988. Anaerobic and aerobic metabolism of diverse aromatic compounds by the photosynthetic bacterium Rhodopseudomonas palustris. Appl. Environ. Microbiol. 54:712-717.

16. Hiraishi, A., Y. K. Shin, J. Sugiyama, and K. Komagata. 1992. Isoprenoid quinones and fatty acids of Zoogloea. Antonie Leeuwenhoek 61:231-236.

17. Höfle, M. G. 1992. Rapid genotyping of pseudomonads by using low-molec ular-weight RNA profiles, p. 116-126. In E. Galli, S. Silver, and B. Witholt (ed.), Pseudomonas: molecular biology and biotechnology. American Society for Microbiology, Washington, D.C.
18. Holt, J. G., N. R. Krieg, P. H. A. Sneath, J. T. Staley, and S. T. Williams (ed.). 1994. Bergey's manual of determinative bacteriology, 9th ed., p. 101. The Williams \& Wilkins Co., Baltimore.

19. Kämpfer, P., K. Bark, H. J. Busse, G. Auling, and W. Dott. 1992. Numerical and chemotaxonomy of polyphosphate accumulating Acinetobacter strains with high polyphosphate:AMP phosphotransferase (PPAT) activity. Syst. Appl. Microbiol. 15:409-419.

20. Kämpfer, P., M. Steiof, and W. Dott. 1991. Microbiological characterization of a fuel-oil contaminated site including numerical identification of heterotrophic water and soil bacteria. Microb. Ecol. 21:227-251.

21. Larsen, N., G. J. Olsen, B. L. Maidak, N. J. McCaughey, R. Overbeek, T. J. Macke, T. L. Marsh, and C. R. Woese. 1993. The Ribosomal Database Project. Nucleic Acids Res. 21:3021-3023.

22. Lysenko, O. 1961. Pseudomonas-an attempt at a general classification. J. Gen. Microbiol. 25:379-408.

23. Macy, J. M., S. Rech, G. Auling, M. Dorsch, E. Stackebrandt, and L. I. Sly. 1993. Thauera selenatis gen. nov., sp. nov., a member of the beta subclass of Proteobacteria with a novel type of anaerobic respiration. Int. J. Syst. Bacteriol. 43:135-142.

24. Maniatis, T., E. F. Fritsch, J. Sambrook. 1982. Molecular cloning: a laboratory manual. Cold Spring Harbor Laboratory, Cold Spring Harbor, N.Y.

25. Medlin, L., H. J. Elwood, S. Stickel, and M. L. Sogin. 1988. The characterization of enzymatically amplified eukaryotic 16S-like rRNA coding regions. Gene 71:491-499.

26. Mezei, L. 1991. Direct purification of PCR product from amplification reactions. Promega note 34. Promega Corp., Madison, Wis.

27. Mohamed, M., B. Seyfried, A. Tschech, and G. Fuchs. 1993. Anaerobic oxidation of phenylacetate and 4-hydroxyphenylacetate to benzoyl-coenzyme $\mathrm{A}$ and $\mathrm{CO}_{2}$ in denitrifying Pseudomonas sp. Arch. Microbiol. 159:563573 .

28. Mullis, K. B., and F. Faloona. 1987. Specific synthesis of DNA in vitro via a polymerase catalyzed chain reaction. Methods Enzymol. 155:335-350.

29. Neefs, J. M., P. De Rijk, Y. Van de Peer, S. Chapelle, and R. De Wachter. 1993. Combination of small ribosomal subunit RNA structures. Nucleic Acids Res. 21:3025-3049.

30. Oyaizu, H., and K. Komagata. 1983. Grouping of Pseudomonas species on the basis of cellular fatty acid composition and the quinone system with special reference to the existence of 3-hydroxy fatty acids. J. Gen. Appl. Microbiol. 29:17-40.

31. Palleroni, N. J. 1984. Gram negative aerobic rods and cocci, p. 141-219. In N. R. Krieg and J. G. Holt (ed.), Bergey's manual of systematic bacteriology, vol. 1. The Williams \& Wilkins Co., Baltimore.

32. Rabus, R., and F. Widdel. Anaerobic degradation of ethylbenzene and other aromatic hydrocarbons by new denitrifying bacteria. Arch. Microbiol., in press.

33. Rech, S. A., and J. M. Macy. 1992. The terminal reductases for selenate and nitrate respiration in Thauera selenatis are two distinct enzymes. J. Bacteriol. 174:7316-7320.

33a.Reinhold-Hurek, B. Personal communication.

34. Reinhold-Hurek, B., T. Hurek, M. Gillis, B. Hoste, M. Vancanneyt, K. Kersters, and J. De Ley. 1993. Azoarcus gen. nov., nitrogen fixing Proteobacteria associated with roots of Kallar grass (Leptochloa fusca (L.) Kunth), and description of two species, Azoarcus indigens sp. nov. and Azoarcus communis sp. nov. Int. J. Syst. Bacteriol. 43:574-584.

35. Rosselló-Mora, R. A., W. Ludwig, and K. H. Schleifer. 1993. Zoogloea ramigera: a phylogenetically diverse species. FEMS Microbiol. Lett. 114:129134

36. Saiki, R. K., D. H. Gelfand, S. Stoffel, S. J. Scharf, R. Higuchi, G. T. Horn, K. B. Mullis, and H. A. Erlich. 1988. Primer-directed enzymatic amplification of DNA with a thermostable DNA polymerase. Science 239:487491.

37. Sanger, F., S. Nicklen, and A. R. Coulson. 1977. DNA sequencing with chain-terminating inhibitors. Proc. Natl. Acad. Sci. USA 74:5463-5467.

38. Schennen, U., K. Braun, and H. J. Knackmuss. 1985. Anaerobic degradation of 2-fluorobenzoate by benzoate-degrading, denitrifying bacteria. J. Bacteriol. 161:321-325.

39. Schocher, R. J., B. Seyfried, F. Vazquez, and J. Zeyer. 1991. Anaerobic degradation of toluene by pure cultures of denitrifying bacteria. Arch. Microbiol. 157:7-12.

40. Seyfried, B., A. Tschech, and G. Fuchs. 1991. Anaerobic degradation of phenylacetate and 4-hydroxyphenylacetate by denitrifying bacteria. Arch. Microbiol. 155:249-255.

41. Stead, D. E. 1992. Grouping of plant pathogenic and some other Pseudomonas spp. by using cellular fatty acid profiles. Int. J. Syst. Bacteriol. 42:281295.

42. Strunk, O., and W. Ludwig. Unpublished data

43. Tschech, A., and G. Fuchs. 1987. Anaerobic degradation of phenol by pure cultures of newly isolated denitrifying pseudomonads. Arch. Microbiol. 148: 213-217.

44. Willems, A., J. De Ley, M. Gillis, and K. Kersters. 1991. Comamonadaceae, a new family encompassing the acidovorans rRNA complex, including Vari- 
ovorax paradoxus gen. nov., comb. nov., for Alcaligenes paradoxus (Davis 1969). Int. J. Syst. Bacteriol. 41:445-450.

45. Willems, A., E. Falsen, B. Pot, E. Jantzen, B. Hoste, P. Vandamme, M. Gillis, K. Kersters, and J. De Ley. 1990. Acidovorax, a new genus for Pseudomonas facilis, Pseudomonas delafieldii, E. Falsen (EF) group 13, EF group 16, and several clinical isolates, with the species Acidovorax facilis comb. nov., Ac- idovorax delafieldii comb. nov., and Acidovorax temperans sp. nov. Int. J. Syst. Bacteriol. 40:384-398.

46. Woese, C. R., W. G. Weisburg, C. M. Hahn, B. J. Paster, L. B. Zablen, B. J. Lewis, T. J. Macke, W. Ludwig, and E. Stackebrandt. 1985. The phylogeny of purple bacteria: the gamma subdivision. Syst. Appl. Microbiol. 6:2533 . 